\title{
ANNOUNCEMENTS
}

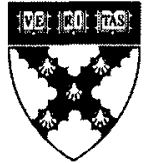

The Editorial Board of the

Business History Review

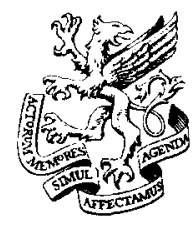

Newcomen Society of the

announce the winners of the

1994 NEWCOMEN AWARDS IN BUSINESS HISTORY

\section{BEST ARTICLE AWARD:}

\section{Carliss $\Upsilon$. Baldwin \\ Harvard University}

and the

\section{Kim B. Clark}

Harvard University

$$
\text { for }
$$

"Capital-Budgeting Systems and Capabilities Investments in U.S. Companies after the Second World War"

\section{SPECIAL ARTICLE AWARD \\ J. Lodge Gillespie, Jr.}

McGraw-Hill Financial Information Services Group

for

"Rhetoric and Reality: Corporate America's Perceptions of Southeast Asia, 1950-1961"

The Editorial Advisory Board of the Business History Review annually awards two prizes to the authors of articles appearing in its pages. The first, consisting of a scroll and cash prize of $\$ 300$, is presented to the author of the best article published in the volume. The second, a cash award of $\$ 150$ and a scroll, is presented to the author of the best article written by a graduate student or recent Ph.D. who has not yet published a book in the field of business history. The awards are made possible through the generosity and support of the Newcomen Society of the United States. 
The Hagley Museum and Library is pleased to announce the recipients of the 1998 Henry Belin du Pont Dissertation Fellowship in Business, Technology, and Society: Anna Vemer Andrzejewski, Department of Art History, University of Delaware; and Stephanie Dyer, Department of History, University of Pennsylvania.

For information about Hagley's research collections and fellowship programs, contact: Center for the History of Business, Technology, and Society, Hagley Museum and Library, P.O. Box 3630, Wilmington, DE 19807. Tel: 302-658-2400; e-mail: crl@udel.edu; internet: www.hagley.lib.de.us

The Ninth Biennial Conference on The History on Historical Research in Marketing and Marketing Thought will be held at Michigan State University, East Lansing, Michigan, 13-16 May 1999. In honor of the centennial of the Seminal Uneeda Biscuit package, MSU's School of Packaging will join the MSU Department of Marketing and Supply Chain Management, the Journal of Macromarketing, and the Academy of Marketing Science in sponsoring this meeting. Original competitive papers are invited on packaging history as well as all other phases of marketing history (broadly defined) in any time period and geographical venue. Papers that deal with methodological, pedagogical, conceptual, or philosophical issues in marketing history are also encouraged. The proceedings volume will be published and outstanding papers will be invited for submission to the history section of the Journal of Macromarketing. For further information, call or write Marketing History Conference, Department of Marketing and Supply Chain Management, The Eli Broad Graduate School of Management, Michigan State University, N370 North Business Complex, East Lansing, Michigan 48824-1122. Tel: 517-3536381; fax 517-432-1112.

The James J. Hill Reference Library will award a number of grants of up to $\$ 2,000$ to support research in the James J. Hill and Louis W. Hill papers. The Hill papers are a rich source for the study of the railroad industry, tourism and Glacier National Park, political developments in the nation and the Northwest, national and regional economic development, agronomy, and many other topies concerned with the Upper Midwest, Pacific Northwest, and Western Canada. Principal correspondents include J. P. Morgan, Mark Hanna, Edward Tuck, E. H. Harriman, American presidents from Grover Cleveland to Woodrow Wilson, Charles Pillsbury, Marcus Daly, George Stephen, Donald Smith, and many others. The deadline for applications is 1 November 1998, and the awards will be announced in early 1999. For more information, contact W. Thomas White, Curator, James J. Hill Reference Library, 80 West Fourth Street, Saint Paul, Minnesota 55102. Tel: 612-265-5441; fax 612-222-4139; email: twhite@jjhill.org

Siena College is sponsoring its fourteenth annual, international, multidisciplinary conference on the 60th anniversary of World War II on 3-4 June 
1999. The focus for 1999 will be 1939 , though papers dealing with broad issues of earlier years will be welcome. Proposals should be rooted in, or show relevance to the anniversary year.

Topics welcomed include, but are not limited to, Fascism and Naziism, the War in Asia, Spain, Literature, Art, Film, Diplomatic, Political and Military History, Preparedness, Popular Culture and Women's and Jewish Studies dealing with the era. Obviously, Post Munich Europe, Danzig, the Molotov-Ribbontrop Pact, Poland, the Phony War, etc., will be particularly appropriate, as will be Asian and African and Near Eastern events of relevance. A brief outline or abstract of the proposal with some sense of sources, archive materials, etc., consulted and a recent c.v. or brief biographical sketch should be sent. Deadline for submissions is 15 November 1998. Final papers are due $15 \mathrm{March} 1999$. Inquiries from those wishing to Chair and/or Comment are also invited.

Replies and inquiries should be addressed to: Professor Thomas $O$. Kelly, II, Department of History, Siena College, 515 Loudon Road, Loudonville, NY 12211-1462. Tel: 518-783-2512; fax: 518-786-5052; email: legendziewic@siena.edu

The European Association for Banking History will award a Prize for an individual scholar or a team of maximum three scholars working on either an institutional, economic or social aspect of the history of European banking or on a biography of a European banker or banker's dynasty. The studies should meet academic requirements, should be unpublished and consist of 80,000 to 120,000 worlds. The applicants should not be over 35 when submitting their manuscripts. The text will be accepted in any European language but will have to be accompanied by an abstract of 3,000 words/10 pages in English.

The Prize of 2,500 ECU's will be awarded in Amsterdam in 1999. In addition the EABH will endeavor to publish the award-winning manuscript. Final submission date for the 1999 Prize is 30 November 1998.

For Further details please contact: Prof. Dr. Manfred Pohl, European Association for Banking History e.V., Zimmerweg 6, D-60325 Frankfurt am Main. Tel: country code + (69) 97203307 ; Fax: country code + (69) 97203 308; e-mail: 106631.240@compuserve.com

The Harvard Business School and the Newcomen Society of the United States announce a postdoctoral fellowship in business history to support twelve months of residence and research at the Harvard Business School for the academic year 1999-2000. The stipend is $\$ 44,000$.

The purpose of this award is to enable scholars who have received the Ph.D. in history, economics, or a related discipline within the past ten years to improve their professional acquaintance with business and economic history, to increase their skills as they relate to this field, and to engage in research that will benefit from the resources of the Harvard Business School and the Boston scholarly community. The successful applicant will participate in the school's business history course, seminar, 
and case development activities. Those interested should request an application from Professor Nancy F. Koehn, Morgan 295, Harvard Business School, Boston, MA 02163. Completed applications for the 1999-2000 Newcomen Fellowship must be received no later than 1 November 1998.

Harvard University announces the Alfred D. Chandler, Jr., Traveling Fellowships in Business History and Institutional Economic History. The grants will range from $\$ 1,000$ to $\$ 3,000$, with the funds awarded each year totaling approximately $\$ 15,000$. The purpose of the fellowships is to facilitate library and archival research in business history or in institutional economic history, broadly defined. Topics such as labor relations and government regulation would also be considered for awards, if the approach is primarily institutional. The intent of the awards is to encourage the kind of research exemplified by the published work of Alfred D. Chandler, Jr.

Three categories of applicants will be eligible for grants:

- Harvard University graduate students in history, economics, business administration, or a related discipline such as sociology, government, or law, whose research requires travel to distant archives or repositories;

- Graduate students or nontenured faculty in those fields from other North American universities, whose research requires travel to the Boston-Cambridge area (to study, for example, in the collections of the Baker, Widener, McKay, Law, Kress, or Houghton libraries);

- Harvard College undergraduates writing senior theses in these fields, whose research requires similar travel.

The fellowships will be administered by a committee of three faculty members from Harvard's Business School and History and Economics departments. The deadline for receipt of applications is 1 December 1998 and recipients may use their awards at any time during calendar 1999.

Requests for applications should be sent to the committee chair, Professor Nancy Koehn, Morgan 295, Harvard Business School, Boston, MA 02163. 